\title{
Mama şi copilul mic: Cine pe cine programează
}

\begin{tabular}{c} 
Sorin Buzinschi \\
Facultatea de Medicină, Universitatea „Transilvania“, Braşov, România \\
\hline
\end{tabular}

\section{REZUMAT}

Viaţa intrauterină este reglată printr-un program epigenetic care adaptează viaţa fetală la condiţiile existente şi la cele probabile. Programarea fetală determinată de tulburări nutriţionale materne se află la originea unor afecţiuni metabolice şi cardiovasculare în copilărie şi viaţă adultă. Programarea maternă dirijează imunitatea copilului, ritmul circadian, răspunsul la stres. Genele imprintate materne şi paterne au o acţiune contradictorie asupra dezvoltării fetale (războiul sexelor). Fătul, la rândul său, programează fiziologia maternă prin hormonii placentari şi prin transferul de celule în organismul matern (microchimerism feto-matern).

Cuvinte cheie: programare materno-fetală, metabolism, imunitate, ritm circadian, stres, conflict parental, programare feto-maternă

\section{INTRODUCERE}

În modelul centrat pe conceptul genetic, influenţa parentală asupra dezvoltării urmaşilor a fost subordonată unui program genetic anterior definit (1). Acumularea de studii experimentale şi clinice a evidenţiat că, de fapt, genele se exprimă în mod diferit în funcţie de mediu. Una dintre cele mai şocante ipoteze medicale de la sfârşitul secolului 20 a fost legătura dintre prematuritate/greutate mică la naştere şi patologia cronică a vârstei adulte (2-4). Considerând că, din punctul de vedere al ciclului de viaţă, cea mai importantă etapă de selecţie naturală are loc prenatal, numeroase studii au demonstrat că există o legătură între nutriţie, condiţiile de viaţă ale mamei şi dezvoltarea intrauterină şi ulterioară a copilului, acestea fiind la originea unor afecţiuni somatice şi psihice. $\mathrm{Cu}$ alte cuvinte, viaţa intrauterină face parte dintr-un program riguros de dezvoltare în care niciun amănunt nu este lipsit de importanţă. Toate aceste adaptări sunt posibile prin modificări ale expresiei genelor fără schimbări în secvenţele ADN, adică prin mecanisme epigenetice. Moştenirea epigenetică se referă la transmiterea unor markeri epigenetici la urmaşi (1), fenotipul fiind rezultatul interferenţei factorilor genetici cu cei proveniţi din mediu (epigenetici).
TABEL 1. Perioade critice în dezvoltarea prenatală

\begin{tabular}{|l|l|l|}
\hline Organe/sisteme & $\begin{array}{l}\text { Sensibilitate } \\
\text { maximă }\end{array}$ & $\begin{array}{l}\text { Dezvoltare până } \\
\text { la }\end{array}$ \\
\hline SNC & 4-8 săptămâni & Postnatal - adult \\
\hline Cord & 5-9 săptămâni & 12 săptămâni \\
\hline Membre & 6-10 săptămâni & 12 săptămâni \\
\hline Ochi & 6-10 săptămâni & Termen \\
\hline Sistem auditiv & 6-11 săptămâni & 13 săptămâni \\
\hline Pancreas (secreție insulină) & 7-? săptămâni & Termen \\
\hline Rinichi & $\begin{array}{l}\text { 8-32 (34) } \\
\text { săptămâni }\end{array}$ & Termen \\
\hline
\end{tabular}

În lumina datelor acumulate, programarea fetală este considerată la originea evenimentelor care se produc din momentul concepţiei, în cursul vieţii intrauterine, a copilăriei şi a perioadei de viaţă adultă, fiind conectate prin fondul epigenetic. Astfel, anumite tulburări relevate în prima parte a vieţii devin predictori ai patologiei adultului. Unele studii devenite ,clasice" au urmărit evoluţia în timp a unor subiecţi supuşi unor restricţii nutriţionale în viaţa intrauterină. În perioada de foamete din Olanda (1944-1945), din cursul celul de-al doilea război mondial, aportul alimentar mediu s-a situat între 300 şi $600 \mathrm{cal} / \mathrm{zi}$. Copiii născuţi în această perioadă au prezentat după 50 ani o structură de patologie care s-a corelat cu perioada de sarcină afectată (7). 
TABEL 2. Sinteză a tipurilor de patologie a adulților de peste 50 ani în funcție de perioada de deprivare nutrițională maternă în Olanda, 1944-1945 (7)

\begin{tabular}{|l|l|l|}
\hline Primul trimestru & Al doilea trimestru & $\begin{array}{l}\text { Al treilea } \\
\text { trimestru }\end{array}$ \\
\hline Intoleranță la glucoză & Intoleranță la & Intoleranță la \\
Afecțiuni & glucoză & glucoză \\
cardiovasculare & Afecțiuni & Afecțiuni \\
HTA & pulmonare & cardiovasculare \\
Dislipidemie & Afecțiuni renale & \\
Obezitate & & \\
Afecțiuni afective & & \\
\hline
\end{tabular}

În numeroase ţări, s-a constatat în ultimele decenii tendinţa la creştere a greutăţii la naştere corelată cu rata crescută de femei supraponderale sau obeze. Hiperglicemia cronică maternă este răspunzătoare de acumularea unui ţesut adipos abundent al nou-născuţilor. Consecințele macrosomiei fetale (greutate la naştere peste 4.000-4.500 g), în mod paradoxal, sunt similare cu cele ale copiilor cu greutate mică la naştere din perspectiva apariţiei DZ în adolescenţă sau în viaţa adultă (8). Un studiu a comparat greutatea copiilor născuţi înainte de chirurgia bariatrică pentru obezitate (macrosomia 34,8\%) cu cei al unui grup de femei după acelaşi tip de chirurgie (macrosomia 7,7\%) (9). Datele sugerează transmiterea intergeneraţională a scăderii toleranţei la glucoză şi a obezităţii pe cale nongenetică. Numeroase date clinice şi experimentale susţin implicarea epigenetică în apariţia obezităţii, a DZ tip 2, a HTA şi a altor afecţiuni.

\section{PROGRAMAREA MATERNĂ A IMUNITĂṬII COPILULUI}

În afară de rolul său nutritiv, laptele matern îndeplineşte şi alte roluri biologice majore: formarea şi modularea imunităţii, transferul de celule vii prin laptele matern, formarea microflorei nou-născutului şi sugarului. Capacitatea laptelui matern de a dezvolta şi modula imunitatea neonatală şi ulterioară se bazează pe transmiterea unei uriaşe cantităţi de informaţie, exprimată prin diferite molecule (citokine, interleukine, defensine, hormoni, factori de creştere, imunoglobuline etc.), celule şi microroganisme. Procesul transmiterii anticorpilor materni către sistemul imun naiv neonatal este iniţiată transplacentar sub acţiunea receptorilor Fc fetali. În colostru şi în laptele matur, au fost identificate imunoglobuline de tip IgG, IgM şi IgA. Persistenţa anticorpilor materni în circulaţia sugarilor se menţine până la vârsts de 9 luni şi este dependentă de debutul producţiei active a acestora (10). Un rol important îl joacă IgA, abundent reprezentat în laptele matern; sub formă de IgA secretor se leagă de stratul de mucus care acoperă celulele epiteliale intes- tinale formând o barieră în faţa germenilor agresivi, înainte de contactul cu celulele epiteliale (11). Ca răspuns faţă de antigenii intestinali proprii, sistemul imun matern produce anticorpi de tip IgA; informaţia imună este transferată plasmocitelor mamare, care, la rândul lor, preiau producţia aceluiaşi tip de anticorpi (sistemul enteromamar). Rezultă colonizarea bacteriană intestinală a nou-născutului cu floră comensală similară cu cea din intestinul matern şi limitarea proliferării patogenilor. Efectul transferului de anticorpi materni la nou-născuţi şi sugari se manifestă numai pe o perioadă relativ scurtă, însă duce la programarea ireversibilă a repertoriului imun, sugerându-se că, în unele cazuri, anticorpii materni pot influenţa funcţia imună pe mai multe generaţii (12). În laptele matern se găsesc bacterii vii care provin din ductele mamare sau areolă, dar în parte sunt componente intrinseci ale laptelui (13). Observaţiile că laptele matern nu este steril, chiar colectat aseptic, sprijină idea că acesta este o sursă de colonizare bacteriană naturală a intestinului neonatal (12). Originea bacteriilor identificate în lapte se găseşte în intestinul matern; observaţia este sprijinită de constatarea că fragmente identice de ADN bacterian pot fi identificate în fecalele materne, sânge, lapte, ca şi în scaunele sugarilor (10). Transferul bacteriilor viabile sau al materialului genetic al acestora este asigurat de celulele mononucleare materne atât în cursul sarcinii, cât şi după naştere (15). Popularea tractului gastrointestinal începe înainte de naştere, deoarece fătul ingerează lichid amniotic care conţine germeni microbieni (14). Chiar dacă compoziţia microbiotei se schimbă cu vârsta, flora microbiană dobândită de la mamă la naştere şi în cursul alimentaţiei naturale va influenţa pe termen lung dezvoltarea mediului microbian intestinal. Programarea imună a intestinului prin lactaţie este asumată şi de transferul de leucocitele vii, active, între care macrofagele şi polimorfonuclearele deţin majoritatea. Populaţia de limfocite transferate sugarului constă în Ly T motile şi interactive, implicate în transferul activ de imunitate $(16,17)$; între acestea, celulele reglatoare Foxp3 (Treg) deţin un rol important in constituirea răspunsului imun tolerogen. Colonizarea bacteriană primară a intestinului este prima lecţie de imunitate a copilului.

\section{PROGRAMAREA RITMULUI CIRCADIAN AL SUGARILOR PRIN ALIMENTATIIA NATURALĂ}

Fiziologia şi comportamentul uman sunt conduse de ritmul circadian guvernat de ciclurile lumină/întuneric şi de metabolismul energetic, sub reglarea SNC $(18,19)$. Formarea ritmului circadian la nou-născuţi şi 
sugari ritmează perioadele de veghe, somn şi solicitările de alimentaţie. Compoziţia laptelui matern variază în cursul zilei. Concentraţia de glucocorticoizi este de 3 ori mai ridicată în laptele matinal decât în eşantioanele recoltate după-amiaza sau seara, stimulând activitatea, pe când nivelul melatoninei este la limita detecţiei în cursul zilei, însă în cursul nopţii creşte la 280 +/- 34 pmol/1 (melatonina fiind cunoscută ca „hormonul somnului“") (20,21). Pe această cale, alimentaţia naturală funcționează prin cronosemnale, ajutând copilul să diferenţieze perioadele de zi-noapte din primele luni de viaţă.

\section{PROGRAMAREA COMPORTAMENTALĂ A COPILULUI PRIN STIMULAREA TACTILĂ}

Este cunoscut faptul că, în primii ani de viaţă, copilul are un comportament fermecător, ceea ce întăreşte legăturile afective cu mama, tatăl sau persoanele apropiate. Acest sistem complex de relaţionare este programat genetic, are scopul de a asigura protecţia şi se întâlneşte la toţi puii de mamifere. Cunoscută ca teoria ataşamentului (attachment theory) (22), ea obiectivează nevoia copilului mic de apărare, de linişte şi de asigurare a aportului alimentar. Comportamentul de ataşare se manifestă pregnant în situaţii de alarmă, însoţite de stres emoţional.

\section{PROGRAMAREA RĂSPUNSULUI LA STRES}

În condiţii experimentale (rozătoare), s-a constatat că îngrijirea atentă a puilor prin contactul tactil matern este responsabilă de un răspuns moderat la stres (comparativ cu puii deprivaţi de îngrijirea maternă) în perioadele următoare de viaţă $(23,24)$. Reacţia la stres implică o serie de modificări ale axei hipotalamo-hipofizo-suprarenale (HHSR) traduse prin creşterea $\mathrm{ACTH}$, a cortizolului, a catecolaminelor etc. Şi la copii s-a constatat că există o legătură între contactul fizic, gradul de îngrijire şi amplitudinea răspunsului la stres, atestat de faptul că îngrijirea maternă atentă diminuează intensitatea reactivităţii la factorii perturbatori din mediu. În aceste situaţii, la nivel molecular, s-a demonstrat creşterea expresiei genei GR (glucocorticoid receptor) în hipocampus, urmată de scăderea răspunsului axului HHSR la stres, modificare transmisă epigenetic şi la etape ulterioare de vârstă $(24,25)$. Oberlander şi colab. (26) au urmărit relaţia dintre comportamentul depresiv/anxios matern în al 3-lea trimestru de sarcină şi creşterea gradului de metilare a genei receptorului celular pentru glucocorticoizi (GRG), urmată de creşterea nivelului cortizolului la vârsta de 3 luni în testările efectuate în salivă. La su- garii în vârstă de 5 luni alimentaţi natural, s-a constatat scăderea gradului de metilare a GRG şi scăderea reactivităţii la cortizol, adică alimentaţia naturală contribuie la reglarea fiziologică a comportamentului (27). Plânsul sugarului (mai ales pe perioade prelungite) reflectă stresul şi disconfortul copilului şi constituie o parte din sistemul de urgenţă în comunicarea sugar-părinţi $(28,29)$. Prezenţa unei frecvenţe ridicate a plânsului (peste $1 \mathrm{kHz}$ ) a fost legată de un control vocal slab, de reglarea deficitară a răspunsului la stres şi poate fi un indicator al integrităţii neurocomportamentale în contextul modificării expresiei GRG (29). Este posibil ca modificările epigenetice în functie de gradul de metilare a GRG să reprezinte un factor cheie în răspunsul la stres, după cum sugerează unele stu$\operatorname{dii}(25,30)$.

Deoarece glucocorticoizii difuzează liber prin membrana celulară, este important să existe și un alt mecanism reglator care să limiteze accesul lor de la mamă în circulația fetală, evitând expresia excesivă a genelor. În condițiifiziologice, există un gradient al glucocorticoizilor de 100-1.000 ori mai mare în circulația maternă față de cea fetală. Carențele din dieta maternă produc scăderea activității enzimei placentare 116-hidroxisteroid-dehidrogenaza (116 HSD2). In condiții standard, aceasta transformă glucocorticoizii activi în forme fără activitate fiziologică, reglând astfel accesul corticosteronului matern la făt. Dacă bariera placentară nu este pe deplin funcțională, pasajul excesiv de glucocorticoizi materni stimulează axul HHSR fetal, cu schimbări somatice și comportamentale ulterioare (anxietate, răspuns la stres, HTA) (44).

\section{CONFLICTUL PARENTAL ÎN PROGRAMAREA FETALĂ}

Dezvoltarea fetală este controlată prin unitatea funcţională dintre mamă, placentă şi făt. Aparent paradoxal, dezvoltarea fătului este determinată de interacţiunea contradictorie dintre genele materne şi paterne în conflictul numit războiul genomic. Efectele antagonice sunt determinate de genele imprintate (care provin de la un singur părinte) care îşi au originea în ovul sau spermă. În această situaţie, unele gene materne pot fi exprimate, iar cele paterne complet inhibate - sau invers, unele gene paterne pot fi active în dauna celor materne.

\section{RĂZBOIUL SEXELOR}

Mama este „interesată“ de supravieţuirea ei, conservarea substraturilor şi diminuarea greutăţii fetale, transmite gene care restrâng creşterea fetală. Tatăl 


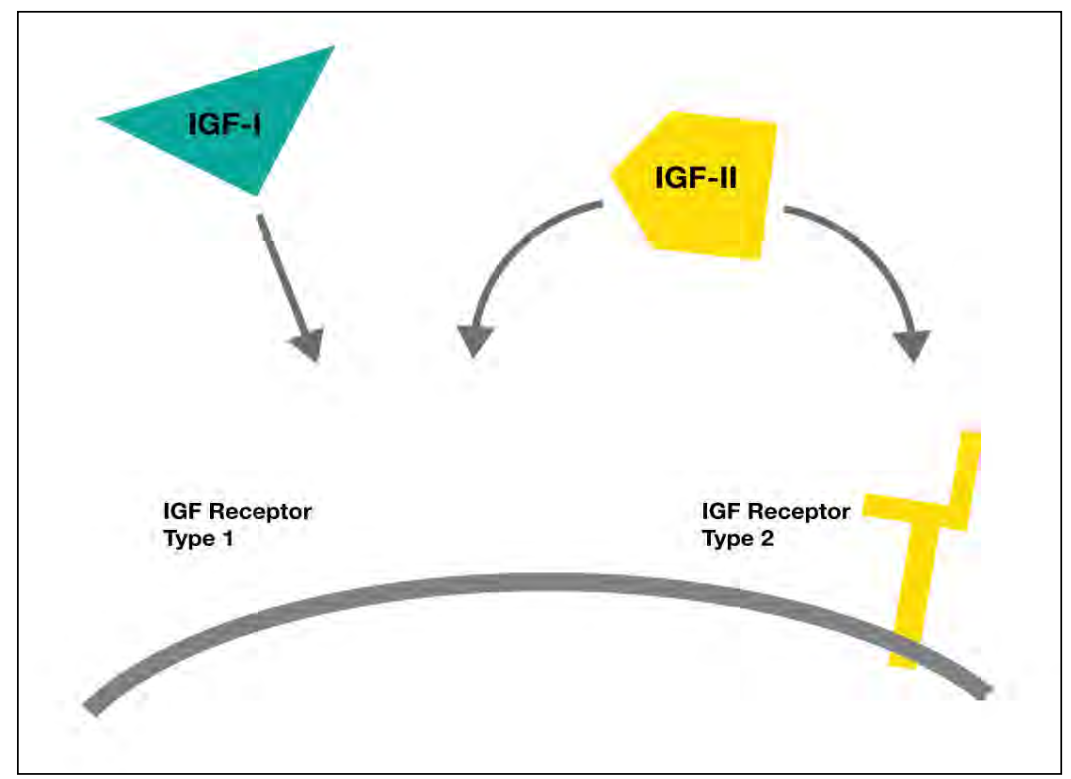

FIGURA 1. Controlul 11ß hidroxisteroid-dehidrogenazei placentare asupra fluxului de glucocorticoizi materni. De remarcat că dexametazona difuzează liber în spațiul placentar

este ,interesat“ în promovarea creşterii fetale, supravieţuire fetală, greutate mai mare la naştere, transmite gene paterne ca IGF-2. Factorii IGF-1 şi IGF-2 stimulează creşterea acţionând asupra receptorului IGF-1r. Al doilea tip de receptor, a cărui genă este de provenienţă exclusiv maternă, IGF-2r, se opune creşterii prin captarea şi degradarea IGF-2 $(31,32)$.

\section{EXISTĂ O PROGRAMARE COPIL-MAMĂ?}

Primele opinii asupra legăturii complexe între mamă şi făt datează din 1993, când Haig (34) a exprimat opinia că genele fetale cresc transferul de nutrienţi către metabolismul fetal, pe când cele materne limitează excesul pasajului acestora. Deşi această opinie poate fi considerată excesivă, trebuie să avem în vedere efectele modificărilor vasculare şi endocrine generate de făt asupra organismului matern.

Reglarea fetală a homeostaziei materne se desfăşoară pe mai multe planuri:

- Vascular-În primele stadii de dezvoltare intrauterină, trofoblaștii (celulele marginale ale blastocistului) migrează în epiteliul uterin matern și transformă arterele spirale endometriale în vase largi cu rezistență scăzută. Pe această cale, fluxul sanguin uteroplacentar ajunge la $25 \%$ din debitul cardiac.

- Endocrin - în cursul sarcinii, placenta devine un organ endocrin important prin producția de estrogeni, progesteron, gonadotropină corionică (hCG), lactogen placentar (hPL) și derivați ai hormonului de creștere (IGF1, IGF2) (45).
Sarcina fiziologică se însoțeşte de rezistenţă la insulină ca adaptare fiziologică a mamei pentru a asigura un aport adecvat de carbohidraţi pentru fătul în creştere rapidă (35). Hormonii produşi de placentă reglează aportul, absorbţia, utilizarea şi transferul nutrienţilor materni către făt (36), totodată fiind la originea rezistenţei la insulină şi, posibil, a diabetului gestaţional. Schimbul bidirecţional de celule vii între mamă şi făt a fost evidenţiat în diferite studii, însă funcţiile celulelor fetale în ţesuturile materne nu sunt clar definite (38-40). Unele celule ale fătului traversează placenta încă din primele săptămâni ale primului trimestru; transferul feto-matern are loc, probabil, în toate sarcinile (39).

\section{MICROCHIMERISMUL FETO-MATERN}

Prezenţa unui număr mic de celule având ca origine un alt subiect diferit genetic de celulele gazdei, denumită microchimerism feto-matern, se caracterizează prin menţinerea un număr de celule fetale în ţesuturile materne pentru o lungă perioadă de timp (decenii) (40). Transferul acestora începe la scurt timp după implantare (38). Celulele fetale sunt circulante în corpul matern, pot coloniza diferite ţesuturi şi pot fi găsite în diferite ţesuturi şi organe materne (de exemplu, sânge, măduvă osoasă, creier, ficat, tegumente) (36). Rolul acestora a fost interpretat fie în interesul copilului, fie în interesul mamei. 


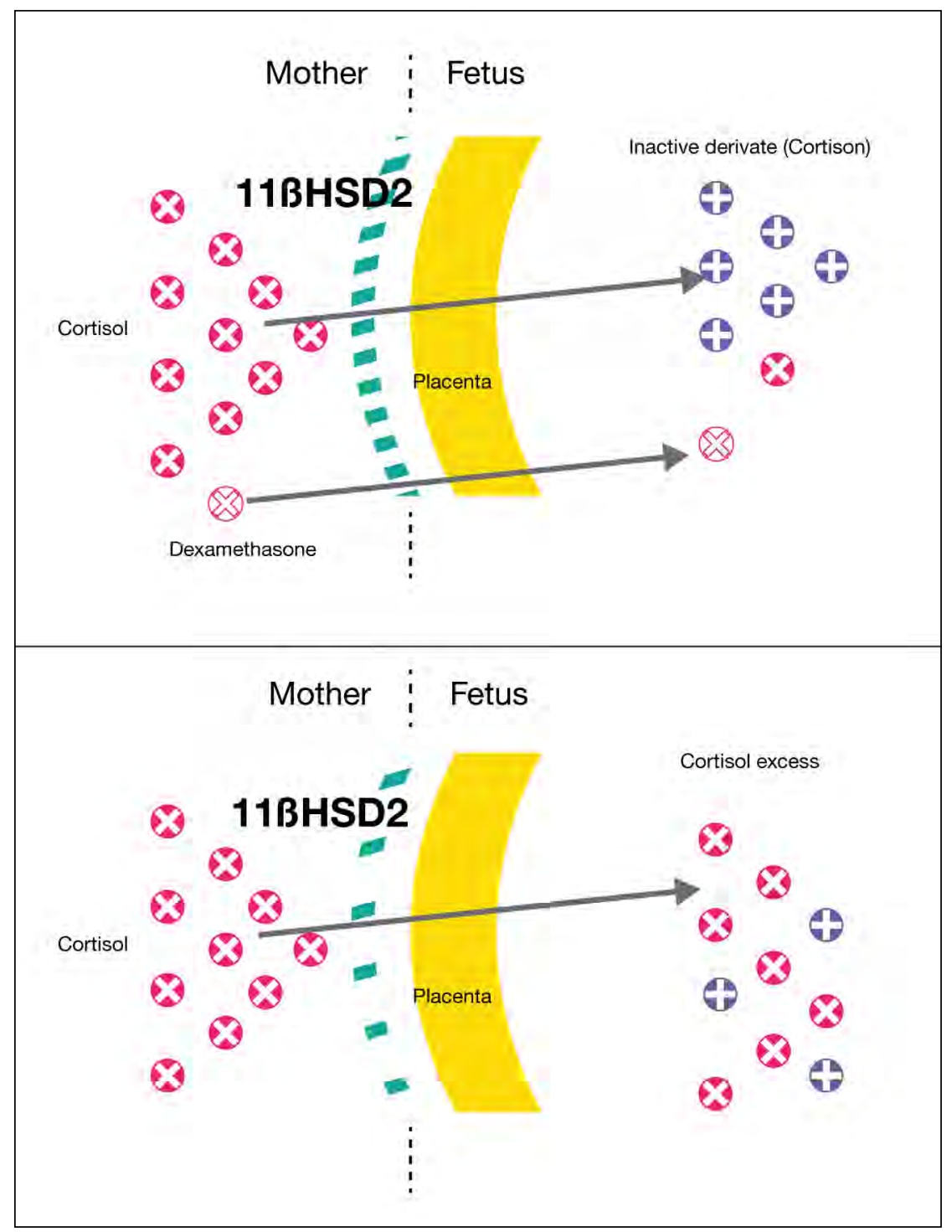

FIGURA 2. Interacțiunea dintre IGF-1, IGF-2 şi receptorii lor în reglarea creşterii fetale în modelul experimental la rozătoare; IGF-1 şi IGF-2 stimulează creşterea intrauterină acționând asupra receptorului IGF-1r. Al doilea tip de receptor, IGF-2r, se opune creşterii prin degradarea IGF-2 (33)

TABEL 3. Relația mamă-copil în cursul sarcinei şi după. Teoria cooperării şi conflictului (negocierea feto-maternă) poate elucida rolul microchimerismului celulelor fetale pentru sănătatea mamei $(38,41)$

\begin{tabular}{|l|l|l|}
\hline $\begin{array}{l}\text { Prezența celulelor } \\
\text { fetale }\end{array}$ & Interesul copilului & Interesul mamei \\
\hline Creier & $\begin{array}{l}\text { Manipularea sistemului neuroendocrin } \\
\text { parental (oxitocină, prolactină) pt nutriție şi } \\
\text { întărirea ataşamentului față de copil }\end{array}$ & $\begin{array}{l}\text { Prezența în creier a ADN-ului celulelor fetale paterne** mulți } \\
\text { ani după naşterea unui fiu; integrare în circuitele neuronale. } \\
\text { Rol în diferențierea neuronilor }\end{array}$ \\
\hline Tiroidă & Creşterea producției de căldură & $\begin{array}{l}\text { Reglarea producției de căldură la un nivel care permite } \\
\text { optimizarea folosirii resurselor în prezent şi pentru viitorii } \\
\text { urmaşi }\end{array}$ \\
\hline Sân & $\begin{array}{l}\text { Celulele fetale migrate la nivelul sânului cresc } \\
\text { producția de lapte prin factori de stimulare } \\
\text { sau prin diferențierea în celule mamare }\end{array}$ & $\begin{array}{l}\text { Modularea producției de lapte; alocarea resurselor în prezent } \\
\text { şi pentru urmaşi }\end{array}$ \\
\hline Sistemul imun & $\begin{array}{l}\text { Inducția toleranței materne } \\
\text { Evitarea detecției şi distrugerii de către } \\
\text { sistemul imun matern }\end{array}$ & $\begin{array}{l}\text { Tolerarea materialului fetal semialogenic. Eliminarea celulelor } \\
\text { fetale care accentuează transferul de resurse la un nivel peste } \\
\text { cel optimal }\end{array}$ \\
\hline
\end{tabular}

\footnotetext{
** Identificate prin prezența cromozomului $Y$
} 
Microchimerismul implică toate tipurile de celule fetale şi trofoblaşti, dar mai ales celule fetale stem (42). Prezenţa unor celule stem-like în diferite linii celulare sugerează capacitatea lor de a se transforma în celule hematopoetice adulte pe toate liniile (42), în celule endoteliale, neuroni, celule musculare netede şi cardiomiocite (41). S-au demonstrat migrarea şi rolul lor în vindecarea leziunilor produse de naşterea prin cezariană prin producerea de colagen tip I, III şi TGF- $\beta$ (43). Pe de altă parte, celulele microchimerice fetale, prin evadarea faţă de sistemul imun matern, au

\section{BIBLIOGRAFIE}

1. Lacal I, Ventura R. Epigenetic Inheritance: Concepts, Mechanisms and Perspectives. Front Mol Neurosci. 2018;11:292.

2. Barker DJ. Fetal origins of coronary heart disease. BMJ. 1995; 311(6998):171-4.

3. Barker DJ, Forsén T, Uutela A, Osmond C, Eriksson JG. Size at birth and resilience to effects of poor living conditions in adult life: Longitudinal study. BMJ. 2001 Dec 1;323(7324):1273-6.

4. Hales C, Barker D. The thrifty phenotype hypothesis. Br Med Bull, 2001; 60:5-20.

5. Delisle H Programming of chronic disease by impaired fetal nutrition. WHO/NHD/02.1/02.3.

6. Buhtta Z, Guerrant R, Nelson CA. Neurodevelopment, Nutrition, and Inflammation: The Evolving Global Child Health Landscape. Pediatrics. 2017 Apr;139(Suppl 1):S12-S22.

7. Boekelheide K, Blumberg B, Chapin R, Cote I Predicting Later-Life Outcomes of Early-Life Exposures. Environ Health Persp. 2012, 120(10):1353-1361.

8. Luke B, Hedinger M. Perinatal Epidemiology of Metabolic Syndrome Risk Factors, in Lipshultz, Messiah, Miller (Eds) Pediatric Metabolic Syndrome, Springer 2012.

9. Smith J, Cianflone K, Biron S et al. Effects of Maternal surgical weight loss in mothers on intergenerational transmission of obesity. J Clin Endocrinol Metab. 2009;94(11):4275-4283.

10. Perez PF, Doré J, Leclerc M, Levenez F, Benyacoub J, Serrant $P$, Segura-Roggero I, Schiffrin EJ, Donnet-Hughes A. Bacterial imprinting of the neonatal immune system: Lessons from maternal cells? Pediatrics. 2007 Mar;119(3):e724-32.

11. Mathias A, Pais B, Favre L, Benyacoub J, Corthésy B. Role of secretory $\lg A$ in the mucosal sensing of commensal bacteria. Gut Microbes. 2014;5(6):688-95.

12. Grindstaff J, Brodie E, Ketterson E. Immune function across generations: Integrating mechanisms and evolutionary process in Maternal antibody transmission. Proc $R$ Soc Lond. 2003;270;2309-19.

13. M'Rabet L, Vos A, Boehm M et al. Breast-feeding and its role in early development of the immune system in infants: Consequences for health later in life. J Nutr. 2008;138(9):1782S-1790S.

14. Prakash S, Rodes I, Cousa-Charley M et al. Gut microbiota: Next frontier in understanding human health and development of biotherapeutics. Biologics: Targets and Therapy, 2001;5:71-86.

15. Romano-Keeler J, Weitkamp JH. Maternal influences on fetal microbial colonisation and immune development. Pediat Res. 2015;77(1-2):189-195.

16. Dzidic M, Boix-Amoros A, Selma-Royo M, Mira A, Collado M. Gut Microbiota and Mucosal Immunity in the Neonate. Med Sci. 2018;6:56.

17. Torow N, Hornef M. The Neonatal Widow of Opportunity: Setting the Stage for Life-Long Host-Microbial Interaction and Immune Homeostasis. J Immunol, 2017;198:557-563.

18. Dibner C, Schibler U, Albrecht U. The Mamalian Circadian Timing System: Organization and Coordination of Central and Peripheral Clocks. Ann Rew Physiol. 2010;72(1):517-549. fost implicate în patogeneza unor cancere şi a unor afecţiuni autoimune (de exemplu, LES, sclerodermia) $(38,41)$.

\section{CONCLUZIE}

$\mathrm{Cu}$ toate aspectele contradictorii, este evident că schimbul de hormoni, imunitate, celule reprezintă o cale de comunicare bidirecţională mamă-copil, care continuă pe alte căi toată viaţa.

Conflict of interest: none declared Financial support: none declared

19. Mendoza J Circadian clocks: setting time by food. J Neuroendocrinol. 2007;19(2):127-137.

20. Pundir S, Wall C, Mitchell $C$ et al. Variation of Human Milk Glucocorticoids over 24 hour Period. J Mammary Gland Biol Neopl, 2017; 22(1):85-92.

21. Illnerova H, Buresova M, Presl J. Melatonin rhytm in human milk. J Clin Endocrinol Metab. 1993;77(3):838-41.

22. Bretherton I. The Origins of Attachment Theory: John Bowlby and Mary Ainsworth. Developmental Psychol. 1992;28:759-75.

23. Caldji C, Tannenbaum B, Sharma A et al. Maternal care during infancy regulates the development of neural systems mediating the expression of fearfulness in the rat. Proc Natl Acad Sci USA, 1998; 95:5335-40.

24. Liu D, Diorio J, Tannenbaum B, Caldji C et al. Maternal Care, Hippocampal Glucocorticoid Receptors, and Hypothalamic-PituitaryAdrenal Responses to Stress. Science, 1997;277:1659-62.

25. Tyrka AR, Parade SH, Welch ES, Ridout KK1, Price LH, Marsit C, Philip NS, Carpenter LL. Methylation of the leukocyte glucocorticoid receptor gene promoter in adults: associations with early adversity and depressive, anxiety and substance-use disorders. Transl Psychiatry. 2016 Jul 5;6(7):e848.

26. Oberlander TF, Weinberg J, Papsdorf M, Grunau R, Misri S, Devlin AM. Prenatal exposure to maternal depression, neonatal methylation of human glucocorticoid receptor gene (NR3C1) and infant cortisol stress responses. Epigenetics. 2008;3(2):97-106.

27. Lester B, Conradt E, La Grasse L et al. Epigenetic Programming by Maternal Behavior in the Human Infant. Pediatrics, 2018;142(4): e20171890.

28. Zeifman D, St James-Roberts I. Parenting the Crying Infant. Curr Opin Psychol. 2017;15:149-54.

29. Sheinkopf SJ, Righi G, Marsit CJ, Lester BM. Methylation of the Glucocorticoid Receptor (NR3C1) in Placenta Is Associated with Infant Cry Acoustics. Front Behav Neurosci. 2016;10:100.

30. Perroud N, Paoloni-Giacombino A, Prada P et al. Increased methylation of glucocorticoid receptor gene (NR3C1) in adults with a history of childhood maltreatment: A link with the severity and type of trauma. Transl Psychiatry 2011;1:e59.

31. Ong K, Kratzsch J, Kiess W et al. Size al birth and cord blood levels of insulin, insulin-like growth factor I (IGF-1), IGF-2, IGF-binding protein-1 (IGFBP-1), IGFBP-3, and the soluble IGF-II/mannose-6phosphate receptor in term human infants. The ALSPAC Study Team. Avon Longitudinal Study of Pregnancy and Childhood. J Clin Endocrinol Metab. 2000;85(11):4266-9.

32. Haig D. Paternal antagonism, relatedness asymmetries, and genomic imprinting. Proc Royal Soc London B, 1997;264:1657-62.

33. Hokken-Koelega A Overview of SGA - www.medscape com/ viewprogram/15701_pnt,2008.

34. Haig D. Genetic conflicts in human pregnancy. Q Rev Biol. 1993; 68(4):495-532. 
35. Sonagra A, Biradar S, Dattatreya K, Murthy J Normal Pregnancy - a State of Insulin Resistance. J Clin Diagn Res. 2014; 8(11):CC01CC03.

36. Freemark M. Placental hormones and the control of fetal growth. Intern J Ped Endocrinol. 2015;Suppl 1:013.

37. Singh R, Hatt L, Ravn $\mathrm{K}$ et al. Fetal cells in maternal blood for prenatal diagnosis: A love story rekindled. Biomarkers Med. 2017;11:9.

38. Dawe GS, Tan XW, Xiao ZC. Cell migration from baby to mother. Cell Adh Migr. 2007 Jan-Mar;1(1):19-27.

39. Sunami R, Komoro M, Yuminamochi T, Hirata S. Fetal cell microchimerism develops through the migration of fetus-derived cells to the maternal organs early after implantation. J Reprod Immunol. 2010;84(1):117-23.

40. Bianchi D, Zickwolf $\mathrm{G}$, Weil $\mathrm{G}$ et al. Male fetal progenitor cells persist in maternal blood for as long as 27 years postpartum. Proc Natl Acad Sci USA 1996;93(2):705-8.
41. Boddy A, Fortunato A, Sayres M, Aktipis A. Fetal microchimerism and maternal health: A review and evolutionary analysis of cooperation and conflict beyond the womb. Bioessays, 2015;37:1106-18.

42. van der Giessen J, Huang VW, van der Woude CJ, Fuhler GM. Modulatory Effects of Pregnancy on Inflammatory Bowel Disease. Clin Trans/ Gastroenterol. 2019 Mar;10(3):e00009.

43. Mahmood U, O'Donoghue K. Microchimeric fetal cells play a role in maternal wound healing after pregnancy. Chimerism, 2014;5(2):40-52.

44. Langley-Evans S. Nutrition: A Lifespan Approach. Wiley-Blackwell, 2009.

45. Murphy VE, Smith R, Giles WB, Clifton VL. Endocrine regulation of human fetal growth: The role of the mother, placenta, and fetus Endocr Rev. 2006;27(2):141-69. 